\title{
The role of UN peace operations in countering health insecurity after COVID- 19
}

Article

Published Version

Creative Commons: Attribution 4.0 (CC-BY)

Open access

Gilder, A. ORCID: https://orcid.org/0000-0002-8861-1433 (2022) The role of UN peace operations in countering health insecurity after COVID-19. Global Policy, 13 (2). pp. 271-280. ISSN 1758-5899 doi: https://doi.org/10.1111/1758-5899.13056 Available at https://centaur.reading.ac.uk/102190/

It is advisable to refer to the publisher's version if you intend to cite from the work. See Guidance on citing.

To link to this article DOI: http://dx.doi.org/10.1111/1758-5899.13056

Publisher: Wiley

All outputs in CentAUR are protected by Intellectual Property Rights law, including copyright law. Copyright and IPR is retained by the creators or other copyright holders. Terms and conditions for use of this material are defined in the End User Agreement.

www.reading.ac.uk/centaur

\section{CentAUR}


Central Archive at the University of Reading

Reading's research outputs online 


\section{The Role of UN Peace Operations in Countering Health Insecurity after COVID-19}

\author{
Alexander Gilder $\mathbb{C}$ \\ University of Reading, Reading, UK \\ Correspondence \\ Alexander Gilder, University of Reading, \\ School of Law, Foxhill House, Reading \\ RG6 6AH, UK. \\ Email: a.f.gilder@reading.ac.uk
}

\begin{abstract}
This Policy Insight suggests the UN must account for a diverse range of conflict drivers, including health insecurity, and that UN peace operations can play a role in countries of deployment to counter health crises. Insecurity is experienced in a variety of different ways in a complex world where threats are multifaceted. COVID-19 is merely the latest health crisis which has impacted populations around the globe in both developed and developing countries. However, UN peace operations have not typically played a major role in addressing health insecurity nor have they undergone any major shifts in their focus to provide direct health-related assistance during the COVID-19 pandemic. With health insecurity likely to persist, there should not need to be a global pandemic for the UN Security Council to use peace operations to undertake further preventative work in this area.
\end{abstract}

\section{I CONSIDERING HOW UN PEACE OPERATIONS CAN RESPOND TO HEALTH INSECURITY}

Today, security crises can take many forms. The UN has a multitude of violent, environmental, economic, health crises and more, to contend with through its many organs. Traditionally, the UN Security Council has focused the UN's peace operations primarily on responding to physical security threats linked to violence. However, individuals and non-state groups are increasingly vocalising concerns over other security threats posed by, for example, the environment, economy, food, and health insecurity that often cross state borders. Health insecurity specifically was prevalent before COVID-19 and encompasses many diseases and failures of public health services that affect vulnerable populations. The COVID-19 pandemic has simply been a vivid exposé of how a non-violent security crisis can emerge and rapidly affect individuals globally requiring international actors to collaborate through a variety of mechanisms. This Policy Insight looks towards the role of UN peace operations in resolving future health crises that may emerge or be identified from the bottom up and require the international community to assist states in administering public health. First, I discuss how security is an increasingly difficult value to protect in the so-called kaleidoscopic world. I explain how UN peace operations remain focused on averting physical violence despite how the notion of security has broadened to include an array of non-traditional threats. Second, I outline how UN peace operations have traditionally taken a subsidiary role in responding to health crises and third, I argue they should increasingly play a more visible role in addressing health insecurity, not only in times of crisis, to respond to needs identified from the bottom up in order to better protect and support vulnerable populations.

This is an open access article under the terms of the Creative Commons Attribution License, which permits use, distribution and reproduction in any medium, provided the original work is properly cited.

(C) 2022 The Authors. Global Policy published by Durham University and John Wiley \& Sons Ltd. 


\section{I SECURITY IN THE KALEIDOSCOPIC WORLD}

Edith Brown Weiss has conceptualised the world as 'kaleidoscopic' where the actors and coalitions engaging in the international system are constantly changing and crises spread quickly around the globe (Brown Weiss, 2011, 2020). Brown Weiss outlines how diseases, pollution, environmental crises, migration, resource scarcities, terrorist networks, and international crime can be issues that rapidly move across borders. Brown Weiss explains there a few key developments that have created the kaleidoscopic world: (1) globalisation of economic and financial sectors that now stretch beyond national borders; (2) the development of communication technologies; (3) an increased focus on empowering people from the bottom-up and less of a focus on top-down methods which has led to the proliferation of civil society and; (4) distribution of dangers to people to areas like climate change, artificial intelligence, cyber space, digital currencies and other scientific developments (Brown Weiss, 2020). In the kaleidoscopic world, actors and coalitions engaging in the international system are constantly changing. Developments are swift where crises can appear and quickly cross borders amidst an ever-connected world linked through information technology.

Security is an 'elastic and dynamic concept' and can broadly be understood as the absence of threats (Booth, 1991; Nasu, 2016). Traditionally, the state has been the referent object of security. That is to say, if the state is able to maintain safety and order internally and is sufficiently capable of repelling external threats then those living within the state are also perceived to be secure. However, in the kaleidoscopic world a crisis in one state can rapidly migrate to other parts of the globe. For instance, environmental changes could cause drought that triggers regionalised violence. These violent threats to physical security, and the root issue of food insecurity, can cause people to flee as refugees or internally displaced persons. There can also be economic ramifications with recession that influences regional and global markets. Suddenly a cascade of security issues has ignored geographic boundaries. Crises that may have once been isolated can now cut to the very core of a person's ability to survive and ultimately drive conflict.

Traditionally, security studies have been principally concerned with national and global security (AndersenRogers \& Crawford, 2018). National security focuses on the stability of the state and its protection from external threats, allowing the state to provide for and protect its inhabitants. Global security focuses on the stability of the international system as a whole. In this traditional understanding of security, it is the state who is the primary security provider. But as has been explained, security issues can be globalised and may require collective action to address or be the result of the state undermining security within its boundaries necessitating a response from the international community.

To recognise the wide range of security threats that can affect individuals, the fact those threats can emanate from the state or sources beyond the control of one state, there has been increased attention given to a human-centric concept of security where the absence of threats for individuals, not only the state as a whole, has been given increased value. ${ }^{1}$ This thinking challenges where states have 'typically defined security in a way where their interests are paramount' (Hanlon \& Christie, 2016, p. 5).

During the Cold War many new concepts were born attempting to recognise the changing nature of security in international affairs recognising the different causes of conflict and declining importance of a state-centric understanding of security. For instance, the Brandt Commission in 1980 stated 'the basis for any world or national order must be people and respect for their essential rights' deeming a state-centric, military focused notion of security as unfit for the world (Independent Commission on International Development Issues, 1980, p. 268). The Palme Commission in 1982 introduced the idea of 'common security' and recognised that states need to consider both economic progress, to ensure the freedom from want, and more traditional, military-based notions of security to ensure the freedom from fear (Palme, 1982). However, common security remained state-centric with the view that 'all states have the right to security' (Owada, 2011, p. 507). The Brundtland Commission in 1987 coined the term 'sustainable development' and importantly considered the environment with an analysis of available resources for the population, food security challenges, different energy sources, and the environment as a cause of conflict (United Nations World Commission on Environment \& Development, 1987). These Commissions laid important groundwork for the reconceptualisation of security towards the individual as the referent object.

In 1994 the United Nations Development Programme (UNDP) attempted to refocus security on the individual by coining the concept of 'human security'. The UNDP's understanding of 'human security' encompassed economic, health, personal, political, food, environmental, and community security to recognise how security and sustainable human development are intrinsically linked (UNDP, 1994). The UNDP became increasingly concerned with security because the needs of people during different forms of emergencies, be it a natural disaster, war, or humanitarian crisis, are increasingly became inseparable from development needs (Murphy, 2006). The Report has been argued to represent a 'broader normative shift leading to the strengthening of the position of individual human beings at the international scene' (Bilkova, 2014, pp. 30-31). This conception of security is important for two core reasons. First, 
the concept of 'human security' emanated from within the UN which allows us to query how UN discourses and practices, such as its UN peace operations, account for different conceptions of security. Second, the UNDP was acknowledging how states had 'for too long focused entirely on conflicts between states and threats to their borders, which individual people have always understood security to mean stability in their daily lives and safety of their surroundings' (Anderson-Rogers \& Crawford, 2018, p. 7). This recognition of lived realties is arguably key for the success of UN peace operations that interact with and provide dividends for local populations.

Notably, the UNDP recognises the importance of health security and outlined examples of how health insecurity can be caused by poor nutrition from food insecurity or polluted water due to environmental insecurity (UNDP, 1994). The UNDP encourage that resources be directed towards the most prevalent threats regardless of the source, be it a state or non-state actor, and that the international community should work towards prevention rather than intervention (Bilkova, 2014).

In 2001, the Commission on Human Security was created by UN Secretary-General Kofi Annan and published its Human Security Now Report two years later. The Commission explained:

Human security means protecting fundamental freedoms-freedoms that are the essence of life. It means protecting people from critical (severe) and pervasive (widespread) threats and situations. It means using processes that build on people's strengths and aspirations. It means creating political, social, environmental, economic, military and cultural systems that together give people the building blocks of survival, livelihood and dignity.

(Commission on Human Security, 2003,

This understanding of human security places a focus on pervasive and widespread threats in an attempt to narrow human security to the core threats to survival and make the concept more practical for operationalisation (Alkire, 2004). Following the report, a number of human security-based initiatives were created within the UN. Namely, a Human Security Unit (HSU) and an Advisory Board for Human Security. The HSU in particular has helped promote and institutionalise the human security concept within the UN (Thérien, 2012). In addition, human security has, been invoked on further occasions: by the General Assembly in thematic debates on the topic, by the International Court of Justice, and by the UN Trust Fund for Human Security (UTFHS). ${ }^{2}$ States too have engaged with the concept, creating groups such as the Human Security Network and the Friends of Human
Security at the General Assembly, and invoking human security in various treaty negotiations such as the Ottawa Convention, the Rome Statute, and the Arms Trade Treaty (Axworthy, 2001; UN, 2008a).

However, within human security lies an important conflict on whether the concept should be interpreted narrowly or broadly. That is to say whether there needs to be a threat of physical violence for there to be a threat to human security. Under a narrow conception, a human security threat exists where there is the risk of physical violence, no matter the root cause be it economic disaster or health epidemic. Conversely the broad conception is distinguished by its recognition that a threat to human security can take many forms, from a multitude of sources, and it is more than violence that can do irreparable damage to human life.

The problem in human security's definition is rooted in the securitisation of the wide variety of threats stretching away from traditional understandings of conflict and violence and it 'involves slapping the label of human security on a wide range of issues that have no necessary link' (Krause, 2004, p. 367). Forceful arguments have been made for human security to focus on violence as part of traditional security thinking by 'point[ing] to the normative success of violence-based human security initiatives' (Owen, 2004a, p. 375). ancerns arise when the threat of violence is present, but not all cases of socio-economic disaster lead to violent action; hence they should not be placed under the rubric of human security' (Acharya, 2001, p. 447). Proponents of the narrow conception argue that a focus on the broader concerns outlined by the UNDP detracts from serious threats individuals face in times of war and conflict (MacFarlane \& Khong, 2006). Threats under the narrow approach are largely traditional including, armed conflict, human rights violations, organised crime and public insecurity (Tadjbakhsh \& Chenoy, 2007).

For example, Canada adopted a human security approach based on pervasive violent threats which undermine the rights, physical safety or lives of people (Moher, 2012). Canada deemed the UNDP articulation as 'unwieldy' and criticised the 1994 Report for ignoring insecurity resulting from violent conflict (Department of Foreign Affairs \& International Trade, 1999). Canada understood that the UN Charter, UDHR and Geneva Conventions represent the core of human security necessitating a focus on violent conflict and physical security (Acharya, 2001). Canada saw the Ottawa Convention on Anti-personnel Landmines, the Rome Treaty creating the International Criminal Court, UN moves to prioritise women and children in armed conflict, and the prevention of small-arms proliferation as developments that made progress on human security (Acharya, 2001; King \& Murray, 2002).

Advocates of narrow definitions point to several examples of where the UN has narrowed its understanding 
of security to conflict and violence. For instance, the Office of the United Nations High Commissioner for Refugees (UNHCR) based its 1997 annual report on human security noting that everyone has a right to security and freedom (MacFarlane \& Khong, 2006; UNHCR, 1997). The report does highlight non-military sources of instability but overall, the report focuses on violence and not development aspects. MacFarlane and Khong (2006) suggest the UNHCR advanced a human rights-based interpretation of human security that is in keeping with the UN system. Likewise, the UN Secretary-General's 1999 report on the legal protection of civilians in armed conflict resulted the UN Security Council indicating 'its willingness to respond to situations of armed conflict where civilians are being targeted or humanitarian assistance to civilians being deliberately obstructed, including through the consideration of appropriate measures at the Council's disposal' (UN, 1999, para 10). Furthermore, the UN Security Council recognised that abuses of humanitarian and human rights law in armed conflict could be deemed threats to international peace and security and so could obstruction of humanitarian assistance (UN, 2000). There has also been long standing work of the UN Security Council on the protection of women and children in armed conflict.

Conversely, proponents of broad definitions argue that due to the fact human security changes the referent object of security away from the state inclusion of the issues beyond violent conflict are necessary (Owen, 2004a). Axworthy says that there must be a recalibration to combat the wider range of harms that have been securitised, essentially saying it is time to move away from, traditional, realist, notions of security (Axworthy, 2004). Tadjbakhsh (2005, p. 7) says that, '[i]f security is ultimately a feeling, then human security must be a felt experience'. The broad approach allows states and international organisations to respond to the needs of individuals as the referent object of security without the existence of a violent security threat.

The shift in security discourses from national and global to human-focused security begs the question whether UN peacekeeping personnel are tasked with dealing with human security, including in a preventative manner, given how crises such as COVID-19 rapidly permeated the lives of communities around the world? It would be a profound policy shift if the UN were to directly combat health insecurity through its peace operations where the UN adopts a broad as opposed to a narrow conception of human security. Such a shift would require recognition that there must be protection against structural threats, such as sudden deprivation or starvation and to live securely and well (Sen, 1999). This is not unbroken ground as in 1992, the then UN Secretary-General, Boutros Boutros-Ghali, highlighted how undermining economic and social development could threaten international peace and security (UN, 1992).

Nevertheless, current UN peace operations retain a focus on physical violence and are not typically mandated to address a broader notion of human security that encompasses any source of a threat than can do irreparable damage to human life (Gilder, 2022). In particular, the protection of civilian strategies mandated by the Security Council emphasise physical protection. ${ }^{3}$ For the UN, protection is 'all about force' and threats to human security beyond physical violence are typically addressed by other UN agencies and NGOs rather than by the UN peace operation. ${ }^{4}$ For instance in Mali, the Food and Agriculture Organization of the United Nations (FAO) has assisted with addressing the food crisis and health security threats have been addressed by UNICEF and the United Nations Mission for Ebola Emergency Response (UNMEER). ${ }^{5}$

It should be noted though that in 2019 Belgium expressed regret that MINUSMA's mandate did not recognise the linkages between climate change and security showing some concern within the Security Council for environmental security (UN, 2019). Similarly, Niger has called for 'not only military but also political, social and economic interventions'. (UN, 2020, p. 16). Despite UN peace operations having not primarily concerned themselves with the broad facets of human security such as environmental degradation, infectious diseases, or economic harm there may be scope for states to support UN peace operations undertaking activities in these areas (Gilder, 2022). This approach would recognise that international responses to insecurity must go beyond both a focus on violence and on the reestablishment of national security.

In the following sections it will be suggested that UN peace operations need more capacity to, at a minimum, support the prevention of health crises that represent a broader notion of human security. Human security aims to provide a bottom-up and localised perspective and set of priorities to address insecurity. Such a perspective that also addresses the context and nexus of conflict is core to the purpose of UN peace operations in the field (Hanlon \& Christie, 2016). The majority of conflicts with which UN peace operations are tasked with engaging are civil wars where the actors seek power and/or resources (Hussien, 2011). These conflicts are not inter-state wars more prevalent in previous centuries where fighting takes place away from civilians. Instead, the conflicts which face peacekeepers are localised and particularly damaging to individuals and communities. This has necessitated a change in how peace operations counter threats resulting in large missions with complex mandates and sweeping powers to protect and build peace. Where conflicts themselves are similarly complex it is important that the UN be able to assess the nexus of the conflict ranging from 
psychological, sociological, economic, and ecological variables to difficulties over determining how best to negotiate a resolution (Hanlon \& Christie, 2016). With expectations ever growing of how the international community should be able to resolve security crises it is important that the UN is able to act in the face of security threats which go beyond physical violence and health insecurity is one example discussed here which UN peace operations could play a more central role.

\section{I UN PEACE OPERATIONS AND PUBLIC HEALTH}

The literature on UN peace operations and health has clearly mapped the relationship between conflict, health, and the role of the UN in that paradigm. We know that where conflict has destroyed infrastructure, host states prioritise military spending, and when health professionals flee, public health services suffer (Reeder, 2018). Access to health in (post)conflict environments also affects women more than men (Gizelis \& Cao, 2021). To combat the decline in public health services in (post)conflict environments, peace operations play a subsidiary role in both providing space for public health services to be (re)established and for humanitarian actors to access the civilian population.

Peacekeepers play a subsidiary role because providing medical assistance is not seen to be one of the 'core functions' of multidimensional peace operations (UN, 2008b, p. 23). The first key role of UN peacekeepers in relation to public health is to provide a secure environment for the provision of health services and the rebuilding of the necessary infrastructure. For example, Gizelis and Cao (2021) found that the secure environment provided by peacekeepers indirectly leads to improved maternal health access. In addition, Reeder has found that where peacekeepers directly target their deployments to violent areas, they consequently have a positive impact on strengthening herd immunity by facilitating vaccinations (Reeder, 2018).

The second role played by a peace operation is directly providing or facilitating humanitarian assistance, which may include medical assistance. Davies and Rushton (2015) categorised the mandates of various missions finding that only three (MONUSCO, MINUSTA and UNAMID) had mandates to provide humanitarian assistance to civilians and more specifically medical assistance. ${ }^{6}$ Instead, the majority of missions at the time had mandates to facilitate access to humanitarian actors who would provide assistance, but in reality the peace operation provided medical assistance where needed (Davies \& Rushton, 2015). Davies and Rushton (2015, p. 28) found 'significant variation in how [peace operations] interpret their role in "facilitating" access' of humanitarian actors and 'more often than not, UN peacekeepers are providing medical assistance to civilians in emergency and nonemergency situations'. A peace operation may also provide short-term or emergent medical assistance through the use of quick impact projects (QIPs). Examples have been given of where medical camps have been set up to provide emergency medical relief and free medical check-ups have been given to schoolchildren (Davies \& Rushton, 2015; Gizelis \& Cao, 2021).

Third, the UN also provides for the health and wellbeing of its own staff and troops. Peacekeepers can be affected by diseases, general ailments, physical injuries, and mental health issues. Davies and Rushton (2015) reported in 2015 that the UN was operating 30 hospitals and 284 clinics, but critiques have been lodged that providing direct assistance to the civilian population undermines the ability of the mission to care for its own personnel. ${ }^{7}$ This may be the case with current mission capacities but a shift in approach by the UN Security Council could lead to a greater allocation of resources for addressing health crises. Serious questions have also been asked about how the UN can be held responsible where its own troops are responsible for health crises that negatively affect the civilian population. As is well known, a Nepalese battalion attached to MINUSTAH introduced cholera to Haiti in 2010 due to inadequate screening protocols. ${ }^{8}$ Freedman and Lemay-Hebert (2015) have suggested the UN was bound by the right to health and consequently is responsible for violations resulting from the cholera outbreak.

One example of where UN peace operations have needed to adapt to counter a non-traditional health threat was in 2014 during the Ebola outbreak. The UN Security Council declared that the 'unprecedented extent of the Ebola outbreak in Africa constitutes a threat to international peace and security' and called on governments to provide assistance with the outbreak (UN, 2014c). This was the first time that the Security Council took a major leadership role during a public health crisis (Davies \& Rushton, 2016). Evidently, the Security Council is willing to recognise under the UN Charter that a health threat can be a threat to international peace and security opening the door for health insecurity to be addressed by a mission's mandate and its personnel.

One mission that shifted to providing health assistance during the Ebola outbreak was the United Nations Mission in Liberia (UNMIL). UNMIL facilitated humanitarian work during the outbreak by continuing its public communication role, donating vehicles, and training local health workers (Davies \& Rushton, 2016). But UNMIL did not involve itself in disease-containment security activities alongside the Liberian government. Despite the identification of a threat to international peace and security and Security Council leadership on 
the matter, UNMIL did not provide direct assistance and in fact reportedly failed to provide its previous levels of assistance on security and health (Davies \& Rushton, 2016).

UNMIL could also have been more proactive if the UN Department for Peacekeeping Operations had identified an 'emergency response period' where humanitarian assistance could be provided directly by the UN forces as opposed to playing only the subsidiary role discussed above. ${ }^{9}$ One author called for UNMIL to go beyond its typical interpretations of physical protection and to interpret its protection of civilians mandate 'to mean supporting the government in its effort to protect the population against a deadly pathogen' (Snyder, 2014). An interpretation in that manner would be a clear recognition of the need to adapt security practices in the kaleidoscopic world to recognise both the complexity of security threats and the needs of individuals. For instance, if a region suffered from a health crisis in which the government's health services were unable to effectively resolve the situation it is currently unclear as to whether the Security Council would recognise the risk of health insecurity as a destabilising force. If recognised as a destabilising force the Security Council could mandate a present UN peace operation to coordinate the response to the health crisis and provide direct assistance alongside building the capacity of the host state's health services.

\section{I ADDRESSING HEALTH INSECURITY IN THE COVID AGE}

There is a clear relationship between conflict and health with the World Health Organization (WHO) Constitution stating, '[t]he health of all peoples is fundamental to the attainment of peace and security and is dependent upon the fullest cooperation of individuals and states' ${ }^{10}$ However, research has shown that current UN peace operations, such as the United Nations Multidimensional Integrated Stabilization Mission in the Central African Republic (MINUSCA), have a preoccupation with physical protection from violent threats due to their adoption of a highly militarised posture (Gilder, 2021). For example, MINUSCA has a preoccupation with 'robustness' and is not primarily concerned with broader facets of insecurity such as environmental degradation, health threats or economic harm (Gilder, 2021). This is not to say that devoting resources toward physical protection is necessarily negative. Capable and robust peacekeepers are more and more what is needed in modern conflicts to provide adequate protection that creates a secure environment for broader peacebuilding activities to take place. ${ }^{11}$ Particularly where the UN is deploying to ongoing rather than postconflict situations, humanitarian access is increasingly difficult to establish.
It must be noted that at their core, current protection of civilian mandates are premised on the goal of protecting civilians from imminent physical danger. ${ }^{12}$ For instance, the three tiers of the UN's protection of civilians strategy includes the provision of physical protection as its second tier (Department of Peacekeeping Operations \& Department of Field Support, 2015). Humanitarian assistance that consequently benefits health services is merely a by-product of the UN's focus on averting physical threats. The current focus on physical protection perpetuates a traditional rhetoric of security and creates tunnel-vision where the peace operation itself becomes preoccupied with a one-track method of protection leaving little space for addressing other complex facets of insecurity and wider peacebuilding objectives.

While physical protection can be what is immediately needed to provide the necessary environment for peacebuilding to take place nonetheless there is a difficult relationship between peacebuilding and the current stabilization mandates that robustly pursue physical protection. Curran and Hunt (2020, p. 59) explain:

[w]hile stabilization at the field level incorporates a certain degree of localism in line with UN peacebuilding policy, this is ultimately subjugated by an overarching militarized and state-centric blueprint for stabilization. In these cases, stabilization is essentially conflated with 'extending state authority'.

Militarised action in contemporary stabilization missions presents two situations: (1) the intensification of conflict preventing access by humanitarian actors; ${ }^{13}$ and (2) close cooperation between UN peacekeeping personnel and the host state. ${ }^{14}$ First, what is needed here is increased recognition in the mandates that peacekeepers operating in hostile environments can provide direct health assistance where other humanitarian actors are unable to gain access or where host state services are inadequate. Second, close cooperation with the host state cannot only be limited to military and law enforcement actions if the UN is to achieve its peacebuilding objectives and avoid the conflation of stabilisation and peacebuilding (Curran \& Hunt, 2020, p. 55). Instead, the UN can support the host state in not only exerting control but also in the rebuilding of critical state functions such as the reestablishment and capacity building of public health institutions alongside the temporary provision of health services by the UN.

Osland and Peter (2021, pp. 205-206) suggest "UN peace operations will not be able to pursue the enlarged agendas of the liberal peacebuilding era" and should leave peripheral tasks to other actors. It is true that UN peace operations cannot provide all services necessary but particularly with regards to current stabilisation missions the UN has closely worked with the host state to build their capacity to exert authority and re-establish 
state functions. Where missions are mandated to undertake tasks in support of establishing state functions this should necessarily include health services. Going further, with Davies and Rushton identifying how missions in reality already provide medical assistance where needed the Security Council should formalise the combatting of health insecurity by its peace operations by including specific tasks in the mandates. With the importance of building peace from below, working towards diverse security threats, such as health or environmental insecurity the Security Council would show crucial regard for the fact threats that permeate the lives of individuals ago beyond violent threats which can be countered by military force (Osland \& Peter, 2021).

The need for the UN to directly provide health assistance may be requested by local communities. The UN's role is to support the creation of conditions under which the local population can achieve a sustainable peace (UN, 2001). In this regard, a UN peace operation should engage the local to determine the full range of local needs and expectations (Richmond, 2012). If communities highlight a need to tackle health insecurity, the mission, and consequently the Security Council, should have the political will to do so. The HIPPO Report recommended in 2015 that, "[o]ngoing community engagement also helps the mission to design better protection strategies to ensure the mission is more effective in improving the lives of the people it is deployed to serve and protect' (UN, 2015a, p. 14). Where communities request direct health assistance due to failings of the state's (post)conflict public health sector a UN response would tie directly to improving the lives of those the mission is present to protect and improve the environment for sustainable peace.

Nevertheless, the UN's immediate response to COVID-19 was not to mobilise in support of public health organizations and prevent potential conflict arising from health insecurity. Some of the UN's initial responses to the outbreak were to pause troops rotations, suspend trainings and other activities with local populations, and in some cases reduce patrols and put UN personnel into lockdown (Danish Institute for International Studies, 2020). Cedric de Coning reported that some of the immediate consequences of COVID-19 were the suspension of quick-impact projects and the redirection of funds to support the host state in containing the virus (de Coning, 2020). It is clear that strategies and policies were not in place for UN peace operations to respond to and act on a health crisis. Richard Gowan and Louis Riis Andersen suggested UN peace operations could have increased funding to manage the consequences of COVID-19 and the UN could offer public health specialists to improve the management of the crisis (Danish Institute for International Studies, 2020).

Arguably though, there should not need to be a global pandemic for the Security Council to pivot the focus of its peacekeeping mandates to respond to threats prioritised by individuals from the bottom up. In the short-term, COVID-19 created unprecedented challenges and the UN needed to be responsive. Over the course of 2020 and 2021 we saw how COVID-19 demands action as it disproportionately affects the vulnerable. However, taking a broader view, health insecurity was prevalent before COVID-19 and encompasses many diseases and failures of health services that affect vulnerable populations.

The Security Council must more clearly streamline health insecurity into the day-to-day work of peace operations as personnel are undeniably already providing medical assistance despite the absence of mandates to do so (Davies \& Rushton, 2015). This may include the inclusion of tasks related to health insecurity in mandates or the creation of policies within the organisation for how missions can respond to health crises. Particularly, where missions are already mandated to undertake tasks in support of establishing state functions this should also include support for building the capacity of health services. This way the UN is prepared to work on health security in a preventative manner by building capacity but also has policies in place for countering a crisis when one arises. Overall, the Security Council must be flexible and be willing to address nonphysical threats such as global health pandemics more directly when they occur, and when their importance is made clear by communities from the bottom up.

To counter the kaleidoscopic world, peace operation mandates need to be more preventative. The UN cannot only fight fires. Its missions must be prepared for crises and this may mean working with the host state and other international partners to pre-empt crises and put the infrastructure in place to reduce the impact of health threats. If a shift in policy is adopted, UN missions would proactively work on both improving the capacity of health services and improving access to those services regardless of whether there is a global pandemic. Missions would then be more prepared, with expertise and experience, to deal with a pandemic if one occurs. Host states would also then expand their close cooperation with the UN beyond military and law enforcement support and have stronger existing relationships in place with the peace operation and other UN actors for supporting health services.

\section{5 | CONCLUSION}

Going forward the Security Council needs to account for a diverse range of conflict drivers be they health threats, environmental degradation, food scarcity and more. COVID-19 has simply highlighted how pervasive one of those threats, health insecurity, can be in a globalised world. The prioritisation of physical security by the UN's large, multidimensional stabilization missions can only achieve so much. Hunt and 
Day (2020) have suggested there could be alternative models of peacekeeping where smaller missions could operate without large military components. Those alternative models could focus on a broad array of security threats that extend beyond threats of physical violence and work with communities to identify local needs. It should not take a pandemic for UN peace operations to respond to health insecurity. Health threats are present in the daily lives of millions. The kaleidoscopic world demands that international actors like the UN have policies and contingencies in place to not only respond but pre-empt complex challenges that affect the lives of individuals and communities, not only threats of violence. By implementing a more diverse view of security and how to protect populations the UN, and host states, would be better prepared for when the local identify a health crisis as requiring action.

\section{ORCID}

Alexander Gilder (1) https://orcid. org/0000-0002-8861-1433

\section{ENDNOTES}

1. For a history see e.g. Daase (2010) and Zwierlein and Graf (2010).

2. The General Assembly's thematic debates resulted in a definition in 2012. See UN (2012)

3. See e.g. UN (2013).

4. This comment is from a humanitarian NGO in South Sudan on differing approaches to the protection of civilians by UNMISS and humanitarian NGOs (Sutton, 2018).

5. See e.g. UN (2014a, 2015b, 2016).

6. See e.g. UN (2014b).

7. For an account of the UN hospital in UNIFIL see Datta and Khanna (2017).

8. See generally, Ivers and Guillaume (2017).

9. See UN (2003).

10. See Constitution of the World Health Organization (entered into force 7 April 1948); see also, Beigbeder (1998).

11. For discussion on the use of force see Beadle and Kjeksrud (2018) Tull (2018).

12. See e.g. UN (2000).

13. On robustness and the intensification of hostilities see e.g. Longobardo (2020), and Gilder (2019).

14. See for example, Laurence (2019) and Kjeksrud and Vermeij (2017).

\section{REFERENCES}

Acharya, A. (2001) Human security: East versus west. International Journal, 56(3), 442-460.

Alkire, A. (2004) A vital core that must be treated with the same gravitas as traditional security threats. Security Dialogue, 35(3), 359-360.

Andersen-Rogers, D. \& Crawford, K. (2018) Human security: Theory and action. Rowan \& Littlefield.

Axworthy, L. (2001) Human security and global governance: Putting people first. Global Governance, 7(1), 19-23.

Axworthy, L. (2004) A new scientific field and policy lens. Security Dialogue, 35(3), 348-349.
Beadle, A.W. \& Kjeksrud, S. (2018) The utility of military force to protect civilians in UN peace operations. In P. Nadin (Ed.) The use of force in UN peacekeeping. Routledge, pp. 100-123.

Beigbeder, Y. (1998) The World Health Organization and peacekeeping. International Peacekeeping, 5(4), 31-48.

Bílkova, V. (2014) Ensuring human security in armed conflicts: The role of non-state actors and its reflection in current international humanitarian law. In C. Ryngaert \& M. Noortmann (Eds.) Human security and international law. Intersensia, pp. 29-51.

Booth, K. (1991) Security and emancipation. Review of International Studies, 17(4), 313-326.

Brown Weiss, E. (2011) International law in a kaleidoscopic world. Asian Journal of International Law, 1(1), 21-32.

Brown Weiss, E. (2020) Establishing norms in a kaleidoscopic world. Brill.

Commission on Human Security. (2003) Human security now. Commission on Human Security.

de Coning, C. (2020) The Impact of COVID-19 on peace operations (IPI Global Observatory, 2 April 2020). Available at: https:// theglobalobservatory.org/2020/04/impact-covid-19-peaceoperations/ [Accessed 10th December 2021].

Constitution of the World Health Organization (entered into force 7 April 1948). Available at: https://apps.who.int/gb/ $\mathrm{bd} / \mathrm{PDF} / \mathrm{bd}$ 47/EN/constitution-en.pdf?ua=1 [Accessed 10th December 2021].

Curran, D. \& Hunt, C.T. (2020) Stabilization at the expense of peacebuilding in UN peacekeeping operations. Global Governance, 26(1), 46-68.

Daase, C. (2010) 'National, societal', and 'human security': On the transformation of political language. Historical Social Research, 35(4), 22-37.

Danish Institute for International Studies (2020) Short-term responses and long-term consequences: Peacekeeping in the shadow of COVID-19 Era. (DIIS Policy Brief). Available at: https://www.diis.dk/en/research/peacekeeping-in-the-shadowof-covid-19-era [Accessed 10th December 2021].

Datta, R. \& Khanna, S. (2017) Leadership challenges in multinational medical peacekeeping operations: Lessons from UNIFIL Hospital. Medical Journal Armed Forces India, 73(4), 414-419.

Davies, S.E. \& Rushton, S. (2015) Healing or harming? United Nations peacekeeping and health (IPI, March 2015). Available at: https:// www.ipinst.org/wp-content/uploads/2015/03/IPI_Rpt_Health_ and_Peacekeeping.pdf [Accessed 10th December 2021].

Davies, S.E. \& Rushton, S. (2016) Public health emergencies: A new peacekeeping mission? Insights from UNMIL's role in the Liberia Ebola outbreak. Third World Quarterly, 37(3), 419-435.

Department of Peacekeeping Operations and Department of Field Support (2015) The protection of civilians in United Nations peacekeeping. (Ref. 2015.07, 1 April 2015). Available at: http:// dag.un.org/bitstream/handle/11176/400960/14\%20November \%202019\%20\%28Protection\%20 of\%20Civilians\%29\%20 $2015.07 \% 20$ Policy \%20 on\%20PoC\%20in\%20Peacekee ping $\% 200$ perations. pdf? sequence $=69 \&$ amp; is All owed $=y$ [Accessed 10th December 2021].

Fastenrath, U., Geiger, R., Khan, D., Paulus, A., von Schorlemer, S. \& Vedder, C. (Eds.) (2011) From bilateralism to community interest: Essays in honour of Bruno Simma. Oxford University Press.

Freedman, R. \& Lemay-Hebert, N. (2015) 'Jistis ak Reparasyon pou tout viktim kolera MINUSTAH': the United Nations and the right to health in Haiti. Leiden Journal of International Law, 28(3), 507-527.

Gilder, A. (2019) The effect of 'stabilization' in the mandates and practice of UN peace operations. Netherlands International Law Review, 66(1), 47-73.

Gilder, A. (2021) Human security and the stabilization mandate of MINUSCA. International Peacekeeping, 28(2), 200-231.

Gilder, A. (2022) Stabilization and human security in UN peace operations. Routledge. 
Gizelis, T. \& Cao, X. (2021) A security dividend: Peacekeeping and maternal health outcomes and access. Journal of Peace Research, 58(2), 263-278.

Hanlon, R. \& Christie, K. (2016) Freedom from fear, freedom from want: An introduction to human security. University of Toronto Press.

Hunt, C.T. \& Day, A. (2020) Why COVID-19 offers a chance to transform UN peacekeeping. (The Conversation, 28 May 2020). Available at: https://theconversation.com/why-covid-19-offers-achance-to-transform-un-peacekeeping-139416 [Accessed 10th December 2021].

Hussien, M. (2011) From state to human security - Institutionalising and operationalising human security in Africa. In: Benedek, W., Kettemann, M. \& Möstl, M. (Eds.) Mainstreaming human security in peace operations and crisis management (Routledge 2011). Abingdon: Routledge.

Independent Commission on International Development Issues. (1980) North-south: A program for survival. MIT Press.

Ivers, L.C. \& Guillaume, Y. (2017) The price of peace? Peacekeeping with impunity harms public health in Haiti. American Journal of Tropical Medical and Hygiene, 97(3), 639-640.

King, G. \& Murray, C. (2002) Rethinking human security. Political Science Quarterly, 116(4), 585-610.

Kjeksrud, S. \& Vermeij, L. (2017) Protecting governments from insurgencies: The Democratic Republic of the Congo and Mali. In C. de Coning, C. Aoi \& J. Karlsrud (Eds.) UN peacekeeping in a new era. Routledge, pp. 227-245.

Krause, K. (2004) The key to a powerful agenda, if properly delimited. Security Dialogue, 35(3), 367-368.

Laurence, M. (2019) 'An 'impartial' force? Normative ambiguity and practice change in UN peace operations. International Peacekeeping, 26(3), 256-280.

Longobardo, M. (2020) 'Super-robust' peacekeeping mandates in non-international armed conflicts under international law. Spanish Yearbook of International Law, 24, 42-72.

MacFarlane, N. \& Khong, Y.F. (2006) Human security and the UN: A critical history. Indiana University Press.

Moher, J. (2012) 'Canada's Human Security Agenda' (Peacebuilding and Human Security Division, Department of Foreign Affairs \& International Trade, Canadian Government, December 2012). Available at: http://odihpn.org/magazine/canada\%C2\%92shuman-security-agenda/ [Accessed 10th December 2021].

Murphy, C.N. (2006) The United Nations Development Programme: $A$ better way? Cambridge University Press.

Nasu, H. (2016) Human security and international law. In M.E. Footer, J. Schmidt, N.D. White \& L. Davies-Bright (Ed.), Security and international law. Hart.

Osland, K.M. \& Peter, M. (2021) UN peace operations in a multipolar order: Building peace through the rule of law and bottom-up approaches. Contemporary Security Policy, 42(2), 197-210.

Owada, H. (2011) Human security and international law. In: Fastenrath, U., Geiger, R., Khan, D., Paulus, A., von Schorlemer, S. \& Vedder, C. (Eds.) From bilateralism to community interest: essays in Honour of Bruno Simma (OUP 2011). Oxford: Oxford University Press, pp. 505-520.

Owen, T. (2004a) Human security - conflict, critique and consensus: Colloquium remarks and a proposal for a threshold-based definition. Security Dialogue, 35(3), 373-387.

Palme, O. (1982) Common security: A programme for disarmament the Report of the Independent Commission on Disarmament and Security Issues under the Chairmanship of Olof Palme. Pan.

Reeder, B.W. (2018) The spatial concentration of peacekeeping personnel and public health during intrastate conflicts. International Peacekeeping, 25(3), 394-419.

Richmond, O. (2012) Beyond local ownership in the architecture of international peacebuilding. Ethnopolitics, 11(4), 354-375.

Ryngaert, C. \& Noortmann, M. (eds) (2014) Human security and international law. Intersensia.

Sen, A. (1999) Development as freedom. Oxford University Press.

Snyder, M.R. (2014) What role for UN peacekeepers in tackling Ebola? (IPI Global Observatory, 8 September 2014). Available at: http://theglobalobservatory.org/2014/09/role-un-peacekeepersunmil-tackling-ebola/ [Accessed 10th December 2021].

Sutton, R. (2018) The 'phantom local' and the everyday distinction practices of humanitarian actors in war: A socio-legal perspective. New Political Science, 40(4), 640-657.

Tadjbakhsh, S. (2005) Human security: Concepts and implications with an application to post-intervention challenges in Afghanistan (Les Études du CERI N 117-118, Sciences Po, September 2005). Available at: https://www.sciencespo.fr/ceri/ sites/sciencespo.fr.ceri/files/etude117_118.pdf [Accessed 10th December 2021].

Tadjbakhsh, S. \& Chenoy, A. (2007) Human security: Concepts and implications. Routledge.

Thérien, J. (2012) Human security: The making of a UN ideology. Global Society, 26(2), 191-213.

Tull, D.M. (2018) The limits and unintended consequences of UN peace enforcement: The force intervention brigade in the DR Congo. International Peacekeeping, 25(2), 167-190.

UN. (1992) An agenda for peace. (17 June 1992) A/47/277.

UN. (1999) Resolution 1265 (17 September 1999) UN Doc S/ RES/1265

UN. (2000) Resolution 1296 (19 April 2000) S/RES/1296.

UN. (2001) No exit without strategy: Security Council decisionmaking and the closure or transition of United Nations peacekeeping operations (20 April 2001) S/2001/394.

UN. (2003) Handbook on United Nations multidimensional peacekeeping operations. United Nations. Available at https://peace keeping.un.org/sites/default/files/peacekeeping-handbook un_dec2003_0.pdf [Accessed 10th December 2021].

UN. (2008a) Letter dated 13 February 2008 from the Permanent Representatives of Japan and Mexico to the United Nations addressed to the President of the General Assembly (15 February 2008) A/62/695.

UN. (2008b) United nations peacekeeping operations: principles and guidelines. UNDPKO. Available at: http://www.un.org/en/ peacekeeping/documents/capstone_eng.pdf [Accessed 10th December 2021].

UN. (2013) Resolution 2100 (25 April 2013) S/RES/2100 para 16(c) (i).

UN. (2014a) Report of the secretary-general on the situation in Mali (23 December 2014) S/2014/943.

UN. (2014b) Resolution 2147 (28 March 2014) S/RES/2147.

UN. (2014c) Resolution 2177 (18 September 2014) S/RES/2177.

UN. (2015a) Identical letters dated 17 June 2015 from the SecretaryGeneral addressed to the President of the General Assembly and the President of the Security Council. (17 June 2015) A/70/95-S/2015/446.

UN. (2015b) Report of the Secretary-General on the situation in Mali. (22 September 2015) S/2015/732.

UN. (2016) Report of the secretary-general on the situation in Mali (28 March 2016) S/2016/281.

UN. (2019) 8568th Meeting (28 June 2019) S/PV.8568.

UN. (2020) Letter dated 9 April 2020 from the president of the security council addressed to the secretary-general and the permanent representatives of the members of the security council $(9$ April 2020) S/2020/286.

UN. (2012) Follow-up to paragraph 143 on human security of the 2005 world summit outcome (25 October 2012) A/RES/66/290.

UNDP. (1994) Human development report 1994. Oxford University Press.

UNHCR. (1997) The State of the World's Refugees 1997: A Humanitarian Agenda. Available at: http://www.unhcr.org/uk/ publications/sowr/3eb789f42/state-worlds-refugees-1997humanitarian-agenda-chapter-2-defending-refugee.html [Accessed 1st January 1997].

United Nations World Commission on Environment and Development. (1987) Our common future. Oxford University Press.

Zwierlein, C. \& Graf, R. (2010) The production of human security in premodern and contemporary history. Historical Social Research, 34(4), 7-21. 


\section{AUTHOR BIOGRAPHY}

Alexander Gilder is Lecturer in International Law and Security at the University of Reading. He is an interdisciplinary researcher and has published on UN peacekeeping, human security, international humanitarian law, international human rights law, and the use of force.
How to cite this article: Gilder, A. (2022) The Role of UN Peace Operations in Countering Health Insecurity after COVID-19. Global Policy, 00, e13056. Available from: https://doi.

org/10.1111/1758-5899.13056 